\title{
Investigation of the Prospective Teachers' Research and Reporting Capabilities of the Written Resources According to Their Branches
}

\author{
Kamil Akbayır \\ Correspondence: Kamil Akbayır, Yüzüncü Yıl University, Faculty of Education, Department of Mathematic and Science \\ Education, Elementary Mathematic Education, Van, Turkey.
}

Received: February 25, 2019

doi:10.11114/jets.v7i4.4090

\author{
Accepted: March 17, 2019 Online Published: March 21, 2019 \\ URL: https://doi.org/10.11114/jets.v7i4.4090
}

\begin{abstract}
The purpose of this study is to examine whether the prospective teachers' researching and reporting capabilities of the written resources varies from branch to branch. The present study is a descriptive study since an existing situation has been exhibited. A total of 97 fourth grade students consisiting of 21 prospective science teacher, 25 mathematic prospective teacher, 24 Turkish prospective teacher and 27 social studies prospective teacher from the Yüzüncü Yll University Faculty of Education Primary School Teacher Education Department have been taken into the sample group during the 2017-2018 spring semester. For the data of this study, a 25-question questionnaire has been developed. The frequencies and the percentages of the data obtained from the questionnaire have been recorded. According to the findings obtained from the study, $75 \%$ of Turkish prospective teachers who participated in our survey had time to study extracurricularly, while $20.8 \%$ became those who spent the most time to study after class by stating that they had sometimes found time, $52 \%$ of mathematic prospective teachers found time to study extracurricularly, $32 \%$ of them sometimes found time to be found among the prospective teachers who participated in our study with the phrase that the least extracurricular teachers have been found. On the other hand, $64 \%$ of mathematic prospective teachers found time to read textbooks, $32 \%$ of them were time to read textbooks with their expressions as sometimes they found time. $41.7 \%$ of Turkish prospective teachers had time to read textbooks, $37.5 \%$ of them sometimes found time, and it was seen that among prospective teachers, it was the branch that found the least time to read textbooks.
\end{abstract}

Keywords: prospective teachers, research, report writing

\section{Introduction}

Research can be perceived as an area of how to do rather than an academic field of study. Research requires skill and experience, and it is an experience that requires independent research and criticism of others' work (Simon \& Burstein, 1985: cited in Balc1, 2009). Research training, from the most simple citizens, various levels of administrators and practitioners, up to the highest level scientists, every exact, different sizes, research formation and culture is required to teach the teaching (Karasar, 1974; Tasdemir \& Tasdemir, 2011). The research self-efficacy is also explained as the student's belief in how much he has the capability to investigate a subject covered by scientific research (Montcalm, 1999; İpek et al., 2010).

According to most studies, there are studies which shows that research taking lessons, teachers to conduct more research in their classrooms, increase their research self-efficacy levels, have high research self-efficacy, are highly relevant in the future to participate in studies and research is high and research concerns decrease ( Green \& Kvidhal, 1990; Krebs, Smither \& Hurley, 1991; Bieschke, Bishop \& amp; Garcia, 1996; Saracaloğlu, 2008: cited in Taşdemir \& Taşdemir, 2011; Unrau \& Beck, 2004; Kahn \& Scott, 1997; Phillips \& Russell, 1994).

Research teaching as the factors affecting the scientific research activities and abilities in the literature are classified as individual characteristics and socio-cognitive factors (İpek et al., 2010). According to the results of the training studies, the research direction of the teachers is very important in order to increase the knowledge and increase the teachers' practices during teaching. However, it is not easy to do research in teaching (Gregson, 2004). For the teachers who work in our education system, there are results which shows that the culture and need of scientific research is not as developed as necessary and that teachers' access to scientific knowledge is limited to the media (İpek et al., 2010).

It is stated that there is a need for advanced mental activities in order to search, summarize a source and report the results (Demirtaş, 1989). In order to provide reliable results to the problems during the research and to ensure the 
continuity and controllability of the information, the results must be reported. The main purpose of the research report is to inform the researcher about the results obtained by the research and to enable the density and controllability in the knowledge. A scientific report must have some characteristics. A few of these features is example, simple, understandable, adapt to the manuscript, write a gripping style and evaluate the results well. Scientific writing is as important as the least produced knowledge. The results of the study, no matter how perfect, are not counted until they are released (Ekmekçi \& Konaç, 2009; Can \& Ceyhan, 2015).

Reporting is a work of skill rather than knowledge. Although there are various ways to reach information, reading continues to be the way of acquiring basic information (Akkaya \& İşci, 2018). Reading habit and knowledge; it is important to create the inner richness of the human being to create his own personality, character and truth, to open up to new horizons and to allow life to be seen with the eyes of the heart as expressed by the Ortaç (2011). Therefore, it is also seen in the studies that it is very important to read and understand what you read for a good research and then to be able to report this information.

Smith (2008), his attitude towards reading; It expresses the mental state of the sensation and emotions, which decreases or increases the likelihood of reading. The individual should understand reading as a way of life other than the free time evaluation and feel that it is indispensable in his own world (Susar Kırmız1, 2012). Reading, when considered as a reproduction, requires writing and imagination as well as writing ability (Akbayır, 2013).

Reading is an event that provides new opportunities for the person to see and guide events and situations. This accumulation and productivity obtained in one's own life is only achieved through strong reading. The construction of knowledge on these strong foundations is made possible by reading which builds the foundation of one's intellectual development (Gönen 2007; Şahenk Erkan, Balaban Dağal \& Tezcan, 2015). In a study conducted in 1998, the data showing that the habit of reading a book in our country has been retreating every past year is shown as follows: $27 \%$ in 1965, 5.7\% in 1980, 2.5\% in 1990 and\% in 19973.5 (CG, 1998; Aslan, Çelik \& Çelik, 2009).

Reading includes a large area that can be perceived as a sign of the level of development of societies. When the rates of reading of developed and developing countries are compared, the difference shows that the situation is not so simple (Özen 2001; Y1lmaz, 2009).

\section{Method}

\subsection{Working Group}

This study, which aims to determine the knowledge and ability levels of pre-service teachers about the research and writing of the written sources, is a research type of descriptive study. The population of the study consist of 97 fourth grade students, 21 prospective science, 25 mathematic teachers, 24 Turkish teachers and 27 social studies teachers.

Table 1. Distribution of the students by branches

\begin{tabular}{lll}
\hline Branches & $\mathrm{f}$ & $\%$ \\
\hline Prospective Science teachers & 21 & 21.6 \\
Mathematic prospective teachers & 25 & 25.8 \\
Turkish prospective teachers & 24 & 24.7 \\
Social studies prospective teachers & 27 & 27.9 \\
Total & 97 & 100 \\
\hline
\end{tabular}

\subsection{Data Collection Tools}

In order to determine the level of knowledge and ability of the students who participated in our study, the data gathered by Demirtaş (1989) was used as a tool to collect information.

In order to develop the questionnaire in accordance with the purpose and scope of the study, a group of students in the lower classes was pre-treated. In addition, the opinions of three specialist faculty members on the subjects of research and writing were selected and the items that were appropriate to be included in the survey were selected. Thus, 25 items were selected and the questionnaire was finalized by subtracting similar substances that did not serve the purpose.

In order to provide the objectivity of the answers given to the questionnaires, the students who answered the questionnaire were not allowed to write a name for the questionnaire. In the first part of the prepared questionnaire, there were questions to determine the prospective of teachers. The relations between the obtained informations are reviewed and divided into two main sections and six subcategory. These subcategories are;

A. Skills related to resource screening: 
1. Reading skills.

2. Ability to use library resources.

3. Note taking and holding skills.

B. Report writing skills:

1. Preliminary knowledge and skills in writing a report.

2. Information and skills related to the format of report writing.

3. Competencies in written expression skills.

\subsection{Data Analysis}

The frequency and percentage values of the answers given to the options of question of each subcategory were created as tables for each branch separately. Then, these tables were interpreted separately to understand findings from the study more easily. In the light of the findings, some results and suggestions are given as follow.

\section{Results}

Table 2. Of the students participating in the study, library, resource screening and homework doing situations

\begin{tabular}{|c|c|c|c|c|c|c|c|c|c|}
\hline Questions & & $\begin{array}{c}\text { Prospective } \\
\text { teacher }\end{array}$ & $\begin{array}{l}\text { science } \\
\text { answers }\end{array}$ & $\begin{array}{c}\text { Mathematic } \\
\text { teacher }\end{array}$ & $\begin{array}{l}\text { prospective } \\
\text { answers }\end{array}$ & $\begin{array}{l}\text { Turkish } \\
\text { teacher }\end{array}$ & $\begin{array}{l}\text { prospective } \\
\text { answers }\end{array}$ & $\begin{array}{c}\text { Social studies } \\
\text { teacher }\end{array}$ & $\begin{array}{l}\text { prospective } \\
\text { answers }\end{array}$ \\
\hline \multirow{4}{*}{$\begin{array}{l}\text { You graduated } \\
\text { high school library } \\
\text { whether or not }\end{array}$} & & $\mathrm{f}$ & $\%$ & $\mathrm{f}$ & $\%$ & $\mathrm{f}$ & $\%$ & $\mathrm{f}$ & $\%$ \\
\hline & Yes & 12 & 57.1 & 14 & 56 & 20 & 83.3 & 14 & 51.8 \\
\hline & No & 9 & 42.9 & 11 & 44 & 4 & 16.7 & 13 & 48.9 \\
\hline & Total & 21 & 100 & 25 & 100 & 24 & 100 & 27 & 100 \\
\hline \multirow[t]{4}{*}{ If there library use } & I use & 1 & 14.3 & 3 & 21.4 & 6 & 30 & 3 & 21.4 \\
\hline & Sometimes & 9 & 64.3 & 9 & 64.3 & 10 & 50 & 11 & 78.6 \\
\hline & I would not use & 2 & 21.4 & 2 & 14.3 & 4 & 20 & - & - \\
\hline & Total & 12 & 100 & 14 & 100 & 20 & 100 & 14 & 100 \\
\hline \multirow{4}{*}{$\begin{array}{l}\text { While in high } \\
\text { school written } \\
\text { homework making }\end{array}$} & I would do & 9 & 42.9 & 13 & 52 & 9 & 37.5 & 10 & 37 \\
\hline & Sometimes & 7 & 33.3 & 12 & 48 & 12 & 50 & 13 & 48.1 \\
\hline & I could not & 5 & 23.8 & - & - & 3 & 12.5 & 4 & 14.9 \\
\hline & Total & 21 & 100 & 25 & 100 & 24 & 100 & 27 & 100 \\
\hline \multirow{4}{*}{$\begin{array}{l}\text { Sources readind } \\
\text { incentive }\end{array}$} & we can & 2 & 9.5 & 5 & 20 & 7 & 29.2 & 7 & 26 \\
\hline & Sometimes & 8 & 38 & 12 & 48 & 10 & 41.6 & 10 & 37 \\
\hline & We would not be & 11 & 52.5 & 8 & 32 & 7 & 29.2 & 10 & 37 \\
\hline & Total & 21 & 100 & 25 & 100 & 24 & 100 & 27 & 100 \\
\hline
\end{tabular}

According to Table 2, the answers given to the questions asked in order to determine the opinions of the prospective teachers participating in the study in the high school that they graduated from, according to the branches, $83.3 \%$ of Turkish prospective teachers had a library in the high school where we graduated. Mathematic with $56 \%$ and social studies prospective teachers with $51.8 \%$ stated that they had libraries in high school.

When we look at the ratio of prospective teachers using the library in our study, $21.4 \%$ of them used library, and $78.6 \%$ of them used the library sometimes. The lowest number of prospective teachers was prospective science teachers with $21.4 \%$.

In order to determine their opinions about whether or not they made written assignments when they were in high school, when the answers of the prospective teachers were examined separately according to the branches, 52\% of the mathematic prospective teachers stated that they did written assignments and $48 \%$ of them stated that they did occasionally. $23.8 \%$ of prospective science teachers stated that they did not do written homework. According to these data, while $100 \%$ of the students who made written assignments in high school were mathematic prospective teachers, $76.2 \%$ of them who were prospective science teachers stated that they did not do, and was the group that least did homework. Other branches are among these.

In order to determine the opinions of the prospective teachers participating in our study in order to determine their opinions about encouraging them to read the sources in high school, $52.5 \%$ of prospective science teachers, $37 \%$ of social studies prospective teachers, $32 \%$ of mathematic prospective teachers and $29.2 \%$ of Turkish prospective teachers stated that they were not encouraged. According to this information, while $52.5 \%$ of prospective science teachers were not the most encouraged, $29.2 \%$ of Turkish prospective teachers were not least encouraged. 
Table 3. Some study areas of the students participating in the study

\begin{tabular}{|c|c|c|c|c|c|c|c|c|c|}
\hline $\begin{array}{l}\text { Branches } \\
\text { Questions }\end{array}$ & & $\begin{array}{c}\text { Prospective } \\
\text { teachers }\end{array}$ & $\begin{array}{l}\text { science } \\
\text { answers }\end{array}$ & $\begin{array}{c}\text { Mathematic } \\
\text { teachers }\end{array}$ & $\begin{array}{l}\text { prospective } \\
\text { answers }\end{array}$ & $\begin{array}{l}\text { Turkish } \\
\text { teachers }\end{array}$ & $\begin{array}{l}\text { prospective } \\
\text { answers }\end{array}$ & $\begin{array}{c}\text { Social studies } \\
\text { teachers }\end{array}$ & $\begin{array}{l}\text { prospective } \\
\text { answers }\end{array}$ \\
\hline \multirow{5}{*}{ Having work plan } & & $\mathrm{f}$ & $\%$ & $\mathrm{f}$ & $\%$ & $\mathrm{f}$ & $\%$ & $\mathrm{f}$ & $\%$ \\
\hline & Yes & 4 & 19 & 7 & 28 & 6 & 25 & 8 & 29.6 \\
\hline & Sometimes & 11 & 52.3 & 11 & 44 & 13 & 52 & 10 & 37 \\
\hline & No & 6 & 28.7 & 7 & 28 & 5 & 23 & 9 & 33.4 \\
\hline & Total & 21 & 100 & 25 & 100 & 24 & 100 & 27 & 100 \\
\hline \multirow{4}{*}{$\begin{array}{l}\text { Compliance } \\
\text { with the work plan }\end{array}$} & I warned & 5 & 24 & 10 & 50 & 4 & 18.2 & 9 & 45 \\
\hline & Sometimes & 8 & 38 & 6 & 30 & 15 & 68.2 & 10 & 50 \\
\hline & I do not fit & 8 & 38 & 4 & 20 & 3 & 13.6 & 1 & 5 \\
\hline & Total & 21 & 100 & 20 & 100 & 22 & 100 & 20 & 100 \\
\hline \multirow{4}{*}{$\begin{array}{l}\text { Preparing } \\
\text { homework }\end{array}$} & Yes & 10 & 47.6 & 16 & 64 & 12 & 50 & 10 & 37 \\
\hline & Sometimes & 10 & 47.6 & 5 & 20 & 8 & 33.3 & 13 & 48.1 \\
\hline & No & 1 & 4.8 & 4 & 16 & 4 & 16.7 & 4 & 14.9 \\
\hline & Total & 21 & 100 & 25 & 100 & 24 & 100 & 27 & 100 \\
\hline \multirow{4}{*}{$\begin{array}{l}\text { Working without } \\
\text { distractions }\end{array}$} & Yes & 5 & 23.8 & 3 & 12 & 4 & 16.7 & 6 & 22.2 \\
\hline & Sometimes & 7 & 33.4 & 9 & 36 & 7 & 29.2 & 9 & 33.4 \\
\hline & No & 9 & 42.8 & 13 & 52 & 13 & 54.1 & 12 & 44.4 \\
\hline & Total & 21 & 100 & 25 & 100 & 24 & 100 & 27 & 100 \\
\hline \multirow{4}{*}{$\begin{array}{l}\text { Getting bored of } \\
\text { listening }\end{array}$} & Yes & 4 & 19 & 4 & 16 & 5 & 20.8 & 5 & 18.5 \\
\hline & Sometimes & 16 & 76.2 & 21 & 84 & 16 & 66.7 & 18 & 66.6 \\
\hline & No & 1 & 4.8 & - & - & 3 & 12.5 & 4 & 14.9 \\
\hline & Total & 21 & 100 & 25 & 100 & 24 & 100 & 27 & 100 \\
\hline
\end{tabular}

According to Table 3, when the answers given to the question asked to determine the views of the prospective teachers who have participated in the study according to the study plan, were examined separately according to the branches, $25 \%$ of the prospective teachers studying in Turkish language had working plan and 52\% of them had it sometimes taking part. As the branch with the most working plan $29.6 \%$ of the social studies teaching had a work plan, $37 \%$ of them were sometimes seen as having a minimum work plan. Other branches are among these.

When we look at the ratio of prospective teachers attending the study in compliance with the work plan, it was observed that $45 \%$ of them followed the working plan and $50 \%$ of them who were social studies prospective teachers followed the plan some times. While the least matching prospective teachers were adopt the plan by $24 \%, 38 \%$ of them were sometimes prospective science teachers.

In order to determine the opinions of the students about the preparation of the homework, when the answers of the prospective teachers are examined separately according to the branches, while $47.6 \%$ of prospective science teachers, $47.6 \%$ of them were sometimes prepared, it was seen that they were most sensitive about preparing homework among the prospective teachers. On the other hand, 50\% of Turkish prospective teachers were prepared and $33.3 \%$ of them were sometimes prepared, it was seen that they were least sensitive about preparing homework among the prospective teachers. Other branches are among these.

When the answers of the prospective teachers were examined separately according to the branches, $23.8 \%$ of the prospective science teachers worked without distracting myself, $33.4 \%$ of them were sometimes distracted, among the prospective teachers were observed that there were prospective teachers who could work most without distracting. In contrast, $16.7 \%$ of Turkish prospective teachers worked without distractions and $29.2 \%$ of them were sometimes distracted, among the prospective teachers were observed that there were prospective teachers who could work least without distracting. Other branches are among these.

In order to determine the opinions of the students about the boredom of the lesson, the answers of the prospective teachers who participated in our study were examined separately according to the branches. It was found that the most bored prospective teachers were mathematic teachers with the ratio of 100\%, $16 \%$ of them stated that they are bored while listening lessons and $84 \%$ of them are sometimes tired of listening lessons. On the other hand, $18.5 \%$ of social studies prospective teachers were bored of listening to lessons, and $66.6 \%$ were sometimes bored with teacher expressions. Other branches are among these. 
Table 4. Success level of students in reading skills

\begin{tabular}{|c|c|c|c|c|c|c|c|c|c|}
\hline Questions & & $\begin{array}{c}\text { Prospective } \\
\text { teacher }\end{array}$ & $\begin{array}{l}\text { science } \\
\text { answers }\end{array}$ & $\begin{array}{c}\text { Mathematic } \\
\text { teacher }\end{array}$ & $\begin{array}{l}\text { prospective } \\
\text { answers }\end{array}$ & $\begin{array}{l}\text { Turkish } \\
\text { teacher }\end{array}$ & $\begin{array}{l}\text { prospective } \\
\text { answers }\end{array}$ & $\begin{array}{r}\text { Social } \\
\text { studies } \\
\text { teacher }\end{array}$ & $\begin{array}{l}\text { prospective } \\
\text { answers }\end{array}$ \\
\hline \multirow{5}{*}{$\begin{array}{l}\text { Find time to study } \\
\text { extracurricular }\end{array}$} & & $\mathrm{f}$ & $\%$ & $\mathrm{f}$ & $\%$ & $\mathrm{f}$ & $\%$ & $\mathrm{f}$ & $\%$ \\
\hline & Yes & 10 & 47.6 & 13 & 52 & 18 & 75 & 16 & 59.3 \\
\hline & Sometimes & 9 & 42.8 & 8 & 32 & 5 & 20.8 & 7 & 25.9 \\
\hline & No & 2 & 9.6 & 4 & 16 & 1 & 4.2 & 4 & 14.8 \\
\hline & Total & 21 & 100 & 25 & 100 & 24 & 100 & 27 & 100 \\
\hline \multirow{4}{*}{$\begin{array}{l}\text { Finding time to } \\
\text { read the textbook }\end{array}$} & Yes & 9 & 42.8 & 16 & 64 & 10 & 41.7 & 11 & 40.7 \\
\hline & Sometimes & 9 & 42.8 & 6 & 24 & 9 & 37.5 & 12 & 44.4 \\
\hline & No & 3 & 14.4 & 3 & 12 & 5 & 20.8 & 4 & 14.8 \\
\hline & Total & 21 & 100 & 25 & 100 & 24 & 100 & 27 & 100 \\
\hline Reading books & Yes & 5 & 23.8 & 8 & 32 & 9 & 37.5 & 9 & 33.3 \\
\hline \multirow{3}{*}{ about lessons } & Sometimes & 14 & 66.7 & 15 & 60 & 6 & 25 & 15 & 55.6 \\
\hline & No & 2 & 9.5 & 2 & 8 & 9 & 37.5 & 3 & 11.1 \\
\hline & Total & 21 & 100 & 25 & 100 & 24 & 100 & 27 & 100 \\
\hline \multirow[t]{4}{*}{ Reading speed } & Fast & 8 & 38.1 & 9 & 36 & 9 & 37.5 & 8 & 29.6 \\
\hline & Middle & 11 & 52.4 & 16 & 64 & 14 & 58.3 & 16 & 59.3 \\
\hline & Slow & 2 & 9.5 & - & - & 1 & 4.2 & 3 & 11.1 \\
\hline & Total & 21 & 100 & 25 & 100 & 24 & 100 & 27 & 100 \\
\hline \multirow{4}{*}{$\begin{array}{l}\text { Read again } \\
\text { reading }\end{array}$} & Yes & 7 & 33.3 & 5 & 20 & 4 & 16.7 & 7 & 25.9 \\
\hline & Sometimes & 11 & 52.4 & 19 & 76 & 16 & 66.6 & 14 & 51.9 \\
\hline & No & 3 & 14.4 & 1 & 4 & 4 & 16.7 & 6 & 22.2 \\
\hline & Total & 21 & 100 & 25 & 100 & 24 & 100 & 27 & 100 \\
\hline \multirow{4}{*}{$\begin{array}{l}\text { Reading } \\
\text { dictionary } \\
\text { use }\end{array}$} & Yes & 1 & 4.8 & - & - & 1 & 4.2 & 2 & 7.4 \\
\hline & when & 7 & 33.3 & 9 & 36 & 14 & 58.3 & 14 & 51.9 \\
\hline & No & 13 & 61.9 & 16 & 64 & 9 & 37.5 & 11 & 40.7 \\
\hline & Total & 21 & 100 & 25 & 100 & 24 & 100 & 27 & 100 \\
\hline \multirow{3}{*}{$\begin{array}{l}\text { Providing } \\
\text { textbooks }\end{array}$} & Yes & 16 & 76.2 & 19 & 76 & 11 & 45.8 & 10 & 37 \\
\hline & No & 5 & 23.8 & 6 & 24 & 13 & 54.2 & 17 & 63 \\
\hline & Total & 21 & 100 & 25 & 100 & 24 & 100 & 27 & 100 \\
\hline \multirow{4}{*}{$\begin{array}{l}\text { Books in read } \\
\text { parts }\end{array}$} & All & 17 & 81 & 23 & 92 & 20 & 83.3 & 20 & 74 \\
\hline & Contents & 1 & 4.8 & 2 & 8 & - & - & 2 & 7.5 \\
\hline & Summary & 3 & 14.4 & - & - & 4 & 16.7 & 5 & 18.5 \\
\hline & Total & 21 & 100 & 25 & 100 & 24 & 100 & 27 & 100 \\
\hline \multirow{4}{*}{$\begin{array}{l}\text { Marking } \\
\text { important } \\
\text { parts }\end{array}$} & Yes & 9 & 42.8 & 17 & 68 & 13 & 54.2 & 11 & 40.7 \\
\hline & Generally & 6 & 28.6 & 6 & 24 & 6 & 25 & 13 & 48.1 \\
\hline & No & 6 & 28.6 & 2 & 8 & 5 & 20.8 & 3 & 11.2 \\
\hline & Total & 21 & 100 & 25 & 100 & 24 & 100 & 27 & 100 \\
\hline \multirow{4}{*}{$\begin{array}{l}\text { Sources } \\
\text { pre-reading }\end{array}$} & Yes & 5 & 23.8 & 2 & 8 & 8 & 33.3 & 8 & 29.6 \\
\hline & Sometimes & 11 & 52.4 & 10 & 40 & 8 & 33.3 & 10 & 37 \\
\hline & No & 5 & 23.8 & 13 & 52 & 8 & 33.3 & 9 & 33.3 \\
\hline & Total & 21 & 100 & 25 & 100 & 24 & 100 & 27 & 100 \\
\hline \multirow{4}{*}{$\begin{array}{l}\text { Using resources in } \\
\text { discussion }\end{array}$} & Yes & 9 & 42.8 & 8 & 32 & 11 & 45.8 & 8 & 29.6 \\
\hline & Sometimes & 11 & 52.4 & 11 & 44 & 8 & 33.3 & 10 & 37 \\
\hline & No & 1 & 4.8 & 6 & 24 & 5 & 20.8 & 9 & 33.3 \\
\hline & Total & 21 & 100 & 25 & 100 & 24 & 100 & 27 & 100 \\
\hline
\end{tabular}

According to Table 4, when we examine the answers to the questions asked to determine the opinions of the prospective teachers who participated in our study on the status of finding time to study extracurricularly, were examined separately according to the branches, $75 \%$ of the Turkish prospective teachers would find time to study, $20.8 \%$ of the time found that the most of the prospective teachers with the expressions in the form of extracurricular reading time was found to be branch. On the other hand, $52 \%$ of mathematic prospective teachers found time to study extracurricularly, $32 \%$ of them were sometimes found to be time-consuming, and it was observed that among prospective teachers, it was the branch that found time to study the least extracurricularly. Other branches are among these.

When the answers of the prospective teachers were examined separately according to the branches, $64 \%$ of the mathematic prospective teachers had time to read the textbook and $32 \%$ of them were time to read textbooks with their expressions as sometimes they would find time. It was seen that they were the branches that found the time to read the most textbooks. In contrast, $41.7 \%$ of Turkish prospective teachers found time to read textbooks, $37.5 \%$ sometimes found time, and it was found that among the prospective teachers, they had the least time to read textbooks. Other branches are among these.

When the answers of the prospective teachers were examined separately according to the branches, $32 \%$ of the 
mathematic prospective teachers read the books about the courses, and $60 \%$ of them stated that they sometimes found time, and it was found that among the prospective teachers that they had the most time to read the books about the courses. In contrast, $37.5 \%$ of the Turkish prospective teachers stated that they found time to read books related to the lessons, and $25 \%$ of them stated that they read sometimes the books. It was seen that they were the least group that read books related to lessons among prospective teachers. Other branches are among these.

When the answers of the prospective teachers were examined separately according to the branches, it was seen that $36 \%$ of the mathematic prospective teachers read fast, $64 \%$ of them were reading at medium speed and there were no one stated that they read slowly. 37.5\% of Turkish prospective teachers stated that they read fast, $58.3 \%$ of them said they read at medium level and $4.2 \%$ said they read slowly. $33.1 \%$ of prospective science teachers stated that they read fast, $52.4 \%$ of them were at medium level reads, $9.5 \%$ stated that they read slowly. $29.6 \%$ of the prospective teachers reported that they read fast, $59.3 \%$ of them read at medium level, and $11.1 \%$ of them read slowly. According to these data, mathematic prospective teachers are the fastest ones while the slowest ones were social studies prospective teachers.

In order to determine the opinions of the prospective teachers who participated in our study, $20 \%$ of the prospective teachers needed to reread what they read and $76 \%$ of them thought that they need to read it again. It is observed that those are the branches that need to read the most among other branches. On the other hand, $25.9 \%$ of social studies prospective teachers need to read again and $51.9 \%$ of them think that they need to re-read what they read. Other branches are among these.

When the answers of the prospective teachers were examined separately according to the branches, $64 \%$ of the mathematic prospective teachers did not use the dictionary while $36 \%$ of them stated that they used the dictionary when they were required. $61.9 \%$ of the prospective science teachers did not use the dictionary while reading, $33.3 \%$ stated that they use the dictionary when they needed to use, $4.8 \%$ of them stated thay they use dictionary while reading. While $40.7 \%$ of the social studies prospective teachers did not use the dictionary while they were reading, $51.9 \%$ of them stated that they used the dictionary when it is needed. $37.5 \%$ of Turkish prospective teachers stated that they did not use a dictionary while 58.3\% stated that they used a dictionary when they need it. According to these datas, the lowest number of teachers who used dictionary was mathematic prospective teachers, the highest number of prospective teachers who used dictionary most were social studies prospective teachers with $7.4 \%$.

In order to determine the opinions of prospective teachers who were asked to determine their opinions about the provision of textbooks, when the answers of the prospective teachers were examined separately according to the branches, $76.2 \%$ of the prospective science teachers were able to provide the highest number of textbooks. On the other hand, it is seen that there is a branch which can provide the least textbooks among the mathematic. Other branches are among these.

When the answers of the mathematic were examined separately according to the branches, $81 \%$ of all prospective science teachers read all of them, $4.8 \%$ of them read the contents, $14.4 \%$ of them read the summary, $92 \%$ of the mathematic prospective teachers read all of them, $8 \%$ of them read the contents, $83.3 \%$ of the Turkish prospective teachers read all of them, $16.7 \%$ of them read the summary and $74 \%$ of the social studies prospective teachers read them all, $7.5 \% 18.5 \%$ stated that they read only the contents.

In order to determine their opinions about whether or not they marked important parts while reading a book, $42.8 \%$ of prospective science teachers stated that they had marked important parts, $28.6 \%$ stated that they usually marked the important parts and $28.6 \%$ of them stated that they do not mark. $68 \%$ of mathematic prospective teachers indicated that they marked important parts, $24 \%$ stated that they usually marked and $8 \%$ of them did not mark important parts. 54.2\% of Turkish prospective teachers stated that they marked important parts, $25 \%$ of them stated that they usually marked and $20.8 \%$ of them did not mark important parts. $40.7 \%$ of the social studies prospective teachers stated that they had marked important parts, $48.1 \%$ stated that they usually marked and $11.2 \%$ of them did not mark important parts.

When the answers of the pre-service teachers were examined separately according to the branches, $23.8 \%$ of the prospective science teachers read the resources in advance and 52.4\% stated that they sometimes read the sources. On the other hand, $8 \%$ of mathematic prospective teachers were found to have read the resources in advance and $40 \%$ of them stated that they read sometimes the resources. It was seen that they were the least group that read resources among prospective teachers. Other branches are among these.

When the answers of the prospective teachers were examined separately according to the branches, $42.8 \%$ of the prospective science teachers used the source in the discussion part, $52.4 \%$ of them stated that they used sometimes source. It was seen that they were the most resource-consuming branch among the prospective teachers in the discussion section. On the other hand, $29.6 \%$ of the social studies prospective teachers used resources in the discussion and $37 \%$ stated that they sometimes used resources. Other branches are among these. 
Table 5. The level of success of students in using library resources

\begin{tabular}{|c|c|c|c|c|c|c|c|c|c|}
\hline $\begin{array}{l}\text { Branches } \\
\text { Questions }\end{array}$ & Pros & & $\begin{array}{l}\text { science } \\
\text { answers }\end{array}$ & $\begin{array}{r}\text { Mathematic } \\
\text { teacher }\end{array}$ & $\begin{array}{r}\text { prospective } \\
\text { answers }\end{array}$ & $\begin{array}{l}\text { Turkish } \\
\text { teacher }\end{array}$ & $\begin{array}{r}\text { prospective } \\
\text { answers }\end{array}$ & $\begin{array}{r}\text { Social } \\
\text { studies } \\
\text { teacher }\end{array}$ & $\begin{array}{l}\text { prospective } \\
\text { answers }\end{array}$ \\
\hline \multirow{4}{*}{$\begin{array}{l}\text { The library you're } \\
\text { using }\end{array}$} & & $\mathrm{f}$ & $\%$ & $\mathrm{f}$ & $\%$ & f & $\%$ & $\mathrm{f}$ & $\%$ \\
\hline & One & 15 & 71.4 & 17 & 68 & 19 & 79.2 & 22 & 81.5 \\
\hline & A few & 6 & 28.6 & 8 & 32 & 5 & 20.8 & 5 & 18.5 \\
\hline & Total & 21 & 100 & 25 & 100 & 24 & 100 & 27 & 100 \\
\hline \multirow{4}{*}{$\begin{array}{l}\text { Having a bookcase } \\
\text { at home }\end{array}$} & There is & 12 & 57.1 & 14 & 56 & 9 & 37.5 & 7 & 25.9 \\
\hline & I'm planning & 8 & 38.1 & 9 & 36 & 15 & 62.5 & 16 & 59.3 \\
\hline & No & 1 & 4.8 & 2 & 8 & - & - & 4 & 14.8 \\
\hline & Total & 21 & 100 & 25 & 100 & 24 & 100 & 27 & 100 \\
\hline \multirow{4}{*}{$\begin{array}{l}\text { The frequency of } \\
\text { going to the library }\end{array}$} & Continuous & - & - & 4 & 16 & 4 & 16.7 & 4 & 14.8 \\
\hline & Sometimes & 20 & 95.2 & 20 & 80 & 19 & 79.2 & 22 & 81.5 \\
\hline & I don’t go & 1 & 4.8 & 1 & 4 & 1 & 4.1 & 1 & 3.7 \\
\hline & Total & 21 & 100 & 25 & 100 & 24 & 100 & 27 & 100 \\
\hline \multirow[t]{4}{*}{ Using library catalogs } & I know & 10 & 47.6 & 11 & 44 & 18 & 75 & 13 & 48.1 \\
\hline & Some & 10 & 47.6 & 9 & 36 & 4 & 16.7 & 9 & 33.4 \\
\hline & I do not know & 1 & 4.8 & 5 & 20 & 2 & 8.3 & 5 & 18.5 \\
\hline & Total & 21 & 100 & 25 & 100 & 24 & 100 & 27 & 100 \\
\hline
\end{tabular}

According to Table 5, when we examine separately according to the branches the answers given to the question asked to determine the number of libraries used by the prospective teachers in our study; $68 \%$ of mathematic prospective teachers use one library, $32 \%$ use several libraries, $79.2 \%$ of Turkish prospective teachers use one library, $20.8 \%$ use several libraries, $81.5 \%$ of social studies prospective teachers while they used one library and $18.5 \%$ stated that they used several libraries.

In order to determine their opinions about whether there is a library in their homes or not, the answers of the prospective teachers who participated in the study were examined separately according to the branches. $57.1 \%$ of prospective science teachers stated that they had a library in their homes, $38.1 \%$ said they planned and $4.8 \%$ stated that they did not have a library. $56 \%$ of the mathematic prospective teachers stated that they had a library in their homes, $36 \%$ said they planned and $8 \%$ said that they did not have a library in their homes. 37.5\% of Turkish prospective teachers stated that they had a library in their homes, $62.5 \%$ said they planned and there was no prospective teacher who stated that there was no library in their homes. $25.9 \%$ of social studies prospective teachers stated that they had a library in their homes, 59.3\% said they planned and $14.8 \%$ said that they did not have a library in their homes.

In order to determine the opinions about the frequencies of going to the library, when the answers of the prospective teachers who participated in the our study were examined separately according to the branches, $94.2 \%$ of the prospective science teachers stated that they went occasionally to the library and $4.8 \%$ said that they did not go at all. Unfortunately there are no prospective science teachers who continuously go to library. $16 \%$ of the mathematic prospective teachers went to the library continuously, $80 \%$ of them went occasionally, $4 \%$ of them did not go at all. $16.7 \%$ of Turkish prospective teachers went to the library continuously, $79.2 \%$ of them went to the library occasionally, $4.1 \%$ of them never went. $14.8 \%$ of social studies prospective teachers went to the library constantly, $81.5 \%$ of them went to the occasional, $3.7 \%$ of them said they never go.

When the answers of the prospective teachers about using library catalogs to reach information are examined separately according to the branches, $47.6 \%$ of the prospective science teachers know how to use library catalogs, $47.6 \%$ of the them know a little, and $4.8 \%$ of the them do not know, $44 \%$ of mathematic prospective teachers know, $36 \%$ know a little, $20 \%$ of them do not know, $75 \%$ of Turkish prospective teachers know, $16.7 \%$ know a little, $8.3 \%$ of them do not know, social studies prospective teachers $48.1 \%$ know, $33.4 \%$ know a little, $18.5 \%$ of the said they did not know.

\section{Conclusion and Suggestions}

Considering that the students' capacity of information and interpretation towards the senior students increases, the scientific research methods course in the faculties of education can be put into the last semester. This may also improve students' ability to conduct research and to conduct scientific research. According to Saraçoğlu (2008), research adequacy affects research variables such as research attitude and research experience.

Weekly lesson hours of scientific research methods can be increased or other educational courses can be used to examine the content of scientific research. This can help students to analyze the work in different disciplines.

Research is the work that is done by the person. What is important in this process is to bring people to the level and request to do research (Üstdal et al., 2004; Taşdemir \& Taşdemir, 2011).

Another point that should not be remembered is that individual work habits and scientific behaviors are not the subject of research lessons alone. The development of these behaviors should be the main aim of the whole educational life of 
the individual and the environment should be arranged accordingly (Karasar, 2007a; Taşdemir \& Taşdemir, 2011).

In this study, which was conducted in order to investigate prospective teachers' research and report writing skills according to the branch, it was found that most of the prospective teachers had the chance to use library in high school. This result is highly promising that future teachers can raise generations to gain reading and research habits. This finding of the study is consistent with the results of Demirtaş (1989), Arslantürk (2008), Saracaloğlu, Yenice \& Karasakaloğlu (2009), Durmuş \& Baş (2016), UNESCO (2014), Clark ve Foster (2005), National Endowment for the Arts (2007), Most of the prospective teachers who participated in our study has a study plan. This finding of the study does not match the results of Demirtaş (1989). Most of the prospective teachers who participated in our study found time to read the extracurricular book and when we examined this situation according to the branches, it was found that Turkish prospective teachers found more time. This finding of the study does not coincide with the research results of Bozpolat (2010) while it is in line with the results of Demirtaş (1989), Şahenk Erkan, Balaban Dağal \& Tezcan (2015). When Bozpolat (2010) is examined in terms of the study department, it is seen that different results are obtained from this study. In a study conducted by Bozpolat (2010), it is seen that the attitudes of prospective teachers (Primary Teacher, Elementary Mathematic Education, Preschool Education, Social Studies Education, Turkish Language Teaching and Science Education) regardless of the departments they study are not changed according to the departments they study.

Another important finding of the study is that the majority of the prospective teachers attending the study went to the library and used library catalogs. While the first part of this finding of the research overlaps with Demirtaş's (1989) research results, the second part does not overlap.

Recommendations of this study for other researchers are listed below:

1) The weekly course hours of scientific research methods should be increased in order to improve the research and report writing skills of the students of the Faculty of Education.

2) As Taşdemir, Taşdemir (2011) stated that the correct information and interpretation capacities of the students towards the last classes have increased, the scientific research methods taught in the faculties of education should be put into the last class.

3) Education faculty students from time to time, instead of exam to make a research related to the topic of the course, the report can be made to print work.

4) Students can read articles related to the content of the course and make oral presentations in the courses.

5) Education faculty students' attitudes towards reading and research should be reviewed periodically and efforts should be made to gain a positive attitude.

6) Education faculty students to gain the habit of reading and to keep this habit in order to sustain their interest in the library should be enriched with current publications.

7) Motivational activities such as reading activities and book promotion days should be organized in order to improve the attitudes of the faculty of education students towards reading habits.

8) Applications can be extended to teachers working in primary and secondary education.

9) Comparisons can be made between different departments of different universities.

\section{References}

Akbayır, S. (2013). Sentence and Text Knowledge. Ankara: Pegem Academy.

Akkaya, N., \& İşci, C. (2018). The relatıonshıp between educatıon faculty students' attıtude toward readıng and theır achievement in written expression course. International Journal of Turkish Literature and Culture Education, 7(2), 1161-1171. https://doi.org/10.7884/teke.4110

Arslan, Y., Çelik, Z., \& Çelik, E. (2009). Determination of university students' attitudes toward reading habit. The Journal of Pamukkale University Faculty of Education, 26, 113-124.

Balc1, A. (2009). Research in Social Sciences: Methods, Techniques and Principles (4th edition). Ankara: Pegem Publishing.

Bozpolat, E. (2010). Evaluation of prospective teachers' attitudes towards reading habits (case of republic university education faculty). Zeitschrift für die Welt der Türken Journal of World of Turks, 2(1), 211-228.

Can, Ş., \& Ceyhan, B. (2015). Opinions of Post-Graduate Students of the Institute of Educational Sciences About Report Writing and Publishing (case of Muğla). Journal Of Social Sciences And Humanities Researches, Autumn, $35,42-51$.

Clark, C., \& Foster, A. (2005). Children's and Young People's Reading Habits and Preferences: The Who, What, Why, 
Where and When, National Literacy Trust.

Cumhuriyet Gazetesi. (1998). 16 July, p.15.

Demirtaş, A. (1989). Written resources and report writing skills of university students. Journal of Hacettepe University Faculty of Education, 4(5), 51-71.

Ekmekçi, A., \& Konaç, E. (2009). Some basic rules of scientific writing. TÜBAV Journal of Science, 2(1), 117-121.

Gönen, M. (2007). Reading habits during reading, reading culture and application problems in schools. MEB Publications, Ankara.

Gregson, R. (2004). Teacher-research: the benefits and the pitfalls. UWS AARE http://www.aare.edu.au/04pap/gre04828. pdf :edinme: 11(5), 2011.

İpek, A. C., Tekbiyık, A., \& Ursavaş, Ö. F. (2010). Research self-efficacy beliefs and computer attitudes of graduate students. Gaziantep University Journal of Social Sciences, 9(1), 127-145.

Kahn, J. H., \& Scott, N. A. (1997). Predictors of Research Productivity and Science-Related Career Goals among Counseling Psychology Doctoral Students. Counseling Psychologist, 25(1), 38-67. https://doi.org/10.1177/0011000097251005

Karasar, N. (1974). Research training. Journal of Ankara University Faculty of Education, 7, 1-4, 263-274.

Karasar, N. (2007a). Scientific research methods (17th edition). Ankara: Nobel Publishing.

Montcalm, D. M. (1999). Applying Bandura's Theory of Self-Efficacy to the Teaching of Research. Journal of Teaching in Social Work, 19(1-2). https://doi.org/10.1300/J067v19n01_08

National Endowment for the Arts (2007). To read or not to read a question of national consequence. 1-99.

Ortaç, İ. (2011). How to gain the habit of reading a book? Are we a book reader? http://turkoloji.cu.edu.tr/genel/ibrahim_ortas_okuma_aliskanligi.pdf, downloaded from 10. 10. 2015.

Özen, F. (2001). Reading Habits in Turkey. T. C. Ministry of Culture Publications, Ankara.

Phillips, J. C., \& Russell, R. K. (1994). Research self-efficacy, the research training environment, and research productivity among graduate students in counseling psychology. The Counseling Psychologist, 22(4), 628-641. https://doi.org/10.1177/0011000094224008

Şahenk, E. S. S., Balaban, D. A., \& Tezcan, Ö. (2015). Evaluation of prospective teachers' printed media and digital reading habits. The Journal of International Education Science, 2(2), 122-134. https://doi.org/10.16991/INESJOURNAL.5

Saracaloğlu, A. S. (2008). The relationship between academic motivation levels, research concerns and attitudes and research competences of graduate students. Journal of Yüzüncü Yll University Faculty of Education, V(II), 179208.

Smith, D. S. (2008). The relationship between learning organizations and student achievement in middle schools (Dissertation). La Verne, California: University of La Verne

Susar, K. F. (2012). An Attitude Scale Towards Prospective Teachers' Reading Habit: Reliability and Validity Analysis. Turkish Studies, 7(3), 2353-2366. https://doi.org/10.7827/TurkishStudies.3372

Taşdemir, M., \& Taşdemir, A. (2011). Scientific research review competences of prospective teachers. Selcuk University Journal of the Institute of Social Sciences, 26, 343-353.

UNESCO (2014). Reading in the mobile era: A study of mobile reading in developing countries. 1-87.

Unrau, Y. A., \& Beck, A. R. (2004). Increasing research self-efficacy among students in professional academic programs. Innovative Higher Education, 28(3), 187-204. https://doi.org/10.1023/B:IHIE.0000015107.51904.95

Üstdal, M., Vullaume, R., Gülbahar, K., \& Gülbahar, Y. (2004). Scientific research guide. İstanbul: Pelikan Publication.

Yılmaz, M. (2009). A study on the reading habits of university students (case of republic university education faculty turkish education department). Journal of Çukurova University Faculty of Education, 3(37), 144-167.

\section{Copyrights}

Copyright for this article is retained by the author(s), with first publication rights granted to the journal.

This is an open-access article distributed under the terms and conditions of the Creative Commons Attribution license which permits unrestricted use, distribution, and reproduction in any medium, provided the original work is properly cited. 